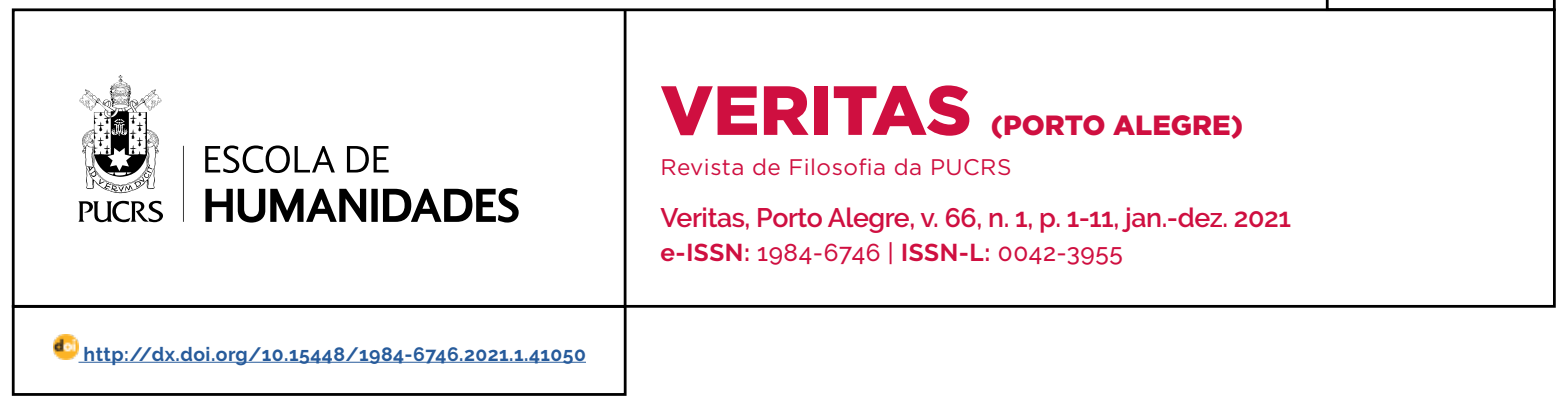

SEÇÃO: EPISTEMOLOGY \& PHILOSOPHY OF LANGUAGE

\title{
Omniscience and ignorance
}

\author{
Omnisciência e ignorância \\ Omnisciencia e ignorancia
}

\section{Duncan Pritchard ${ }^{1}$}

orcid.org/0000-0002-5997-0752

dhpritch@uci.edu

Received on: Jun. 4, 2021. Approved on: Sep. 20, 2021. Published on: Nov. 3, 2021.
Abstract: God's omniscience generates certain puzzles, not least regarding how such omniscience is compatible with human free will. One option in this regard is to impose limitations on the scope of God's knowledge, but that then poses the further question of how such limitations can be compatible with God's nature as a perfect being. I offer a novel way of approaching these questions, which appeals to what I claim is an independently motivated distinction between lacking knowledge and being ignorant. In particular, it is contended that God's omniscience is best understood not as a complete knowledge of all truths, but rather as a kind of deliberate non-knowing (such that the non-knowing does not indicate any cognitive lack on God's part) that excludes ignorance. God might not know all truths, but that's not because of any cognitive lack, and there is certainly no truth about which he is ignorant.

Keywords: Epistemology. God. Ignorance. Omniscience. Philosophy of Religion.

Resumo: A onisciência de Deus gera certos enigmas, e não menos a respeito de como tal onisciência é compativel com o livre arbitrio humano. Uma opção a este respeito é impor limitações ao escopo do conhecimento de Deus, mas isso levanta a questão adicional de como tais limitações podem ser compativeis com a natureza de Deus como um ser perfeito. Eu ofereço uma nova maneira de abordar essas questões, que apela para o que eu afirmo ser uma distinção motivada de forma independente entre falta de conhecimento e ser ignorante. Em particular, afirma-se que a onisciência de Deus é melhor entendida não como um conhecimento completo de todas as verdades, mas sim como um tipo de não conhecimento deliberado (de modo que o não conhecimento não indica qualquer carência cognitiva da parte de Deus) que exclui ignorância. Deus pode não saber todas as verdades, mas isso não é devido a qualquer carência cognitiva, e certamente não há nenhuma verdade sobre a qual ele seja ignorante. Palavras-chave: Epistemologia. Deus. Ignorância. Onisciência. Filosofia da Religião.

Resumen: La omnisciencia de Dios plantea ciertos enigmas, sobre todo en cuanto a cómo tal omnisciencia es compatible con el libre albedrío humano. Una opción a este respecto es imponer limitaciones al alcance del conocimiento de Dios, pero esto plantea la pregunta adicional de cómo tales limitaciones pueden ser compatibles con la naturaleza de Dios como un ser perfecto. Ofrezco una nueva forma de abordar estas preguntas que apela a lo que afirmo es una distinción motivada independientemente entre falta de conocimiento y ser ignorante. En particular, se argumenta que la omnisciencia de Dios se entiende mejor no como un conocimiento completo de todas las verdades, sino más bien como una especie de no conocimiento deliberado (de modo que el no conocimiento no indica ninguna deficiencia cognitiva por parte de Dios) que excluye la ignorancia. Dios puede no conocer todas las verdades, pero eso no se debe a ninguna deficiencia cognitiva, y ciertamente no hay verdad sobre la cual él sea ignorante". Palabras clave: Epistemología. Dios. Ignorancia. Omnisciencia. Filosofia de la religión. 
1. If there is a God, then it seems that he must be the kind of being that is omniscient. God, after all, is a perfect being, and yet a lack of knowledge would imply an imperfection. The problem, however, is that God's putative omniscience seems to run counter to some of the other properties that we might naturally attribute to such a being. Examples are legion, but here are a few. If God is an immaterial being (and it is hard to see how he could be otherwise), then how can he have knowledge of anything that would presuppose sensory experience of the world, such as the distinctive feel of sand flowing through one's fingers? If God exists outside space and time, as is commonly thought, then how can he have knowledge of tensed claims about the world, such as that the movie is about to finish? If God is a perfect being, then how can he know what it is like to experience the kinds of thoughts and feelings that can only be had by non-perfect beings, such as feelings of frustration and fear, or being plagued by the kind of thoughts involved in self-doubt? The most familiar kind of tension between God's omniscience and his other properties concerns, however, the claim that God's perfect goodness would entail that he grants us free will. For how can our free actions be compatible with God's omniscience if that extends to his (presumably infallible) foreknowledge of what we will do?

These kinds of issues naturally lead to qualifications to the omniscience thesis, either to the extent that there is less to be known than we might have otherwise thought (e.g., that the future is open, so there are no facts about our specific actions in the future for God to foreknow), or that there are limitations on God's omniscience (i.e., there are principled reasons for thinking that an omniscient being could consistently not know certain facts). I want to outline a new way of approaching this topic, albeit a variation on the latter of these proposals.

Omniscience, I will claim, need not be exclusively understood in terms of the boundless nature of a subject's knowledge, but can also be coherently thought of as the absence of ignorance. As we will see, there can be facts that one does not know without one thereby being ignorant of those facts. Accordingly, while it would be contrary to the nature of God for him to be ignorant of any fact, it needn't thereby be contrary to his nature for him to not know a fact, at least so long as this lack of knowledge is not indicative of either ignorance or of a cognitive limitation on God's part. We thus get a novel way of making sense of how God might not know certain facts while nonetheless remaining (in the specific sense that we have specified) omniscient.

2. Omniscience is normally, and quite naturally, understood in terms of the complete possession of knowledge. For our purposes, we can restrict our attention to propositional knowledge, so long as we bear in mind that there are potentially other kinds of knowledge that might be relevant in this regard, such as a kind of direct acquaintance with elements of reality. ${ }^{2}$ With that in mind, I will follow Linda Zagzebski (2013a, p. 310) in treating the "standard account of omniscience" as involving knowing "the truth value of every proposition." So if God is omniscient, then he doesn't just know all true propositions, but also knows when a proposition is false too. ${ }^{3}$

\footnotetext{
Indeed, Zagzebski (2013a, p. 311) points out the oddity of conceiving of God's epistemic access to the world as being mediated via an abstract object like a proposition. Even if one grants that God has propositional knowledge, however, it is hard to see how all of his knowledge could be propositional in form. Zagzebski $(2008,2013 \mathrm{~b}, 2016)$, for example, regards God as possessing an attribute she calls omnisubjectivity, whereby God has the capacity to grasp our first-person experiences. This would presumably involve a kind of de se knowledge that is at least arguably not reducible to propositional knowledge. See also endnote 4 . Note that even if we restrict ourselves to propositional knowledge, there are some potential further complications, as it isn't straightforward how God would satisfy the conditions for propositional knowledge, at least as we usually understand that notion. For example, human knowledge that $p$, at least, is typically thought to entail that the subject believes that $p$, and yet it has been argued that God can't credibly be thought to have beliefs. For discussion of this point, see Alston (1986) and Hasker (1988). Similarly, it has been argued that it is in the nature of human knowledge that it is skillfully acquired - see, for example, Sosa (e.g., 2007), Greco (2009), or Pritchard (2012) - but it is not clear how this condition would apply when it comes to God's knowledge, given that it isn't obviously acquired at all.

And if there is some third truth-value that is applicable here, then God knows that the proposition enjoys that truth value too. Note that one could arguably replace this account of omniscience with a simpler version that simply says that God knows all truths, as the class of all truths will presumably also include truths about which propositions are false (or have a third truth-value, etc). For some other useful discussions of omniscience, see Wierenga (2009, 2021), Maverodes (2010), and Wainwright (2010).
} 
How would such an account of omniscience square with the problems we have noted? Some of these problems could be cast as being concerned with a non-propositional form of knowledge, and hence God could be omniscient in the way just defined - i.e., knowing all (propositional) truths - while nonetheless lacking the target (non-propositional) knowledge. Knowing what it is like to be afraid, for example, might be best thought of in non-propositional terms as a kind of experiential acquaintance knowledge. ${ }^{4}$ As regards tensed truths one might contend that nothing essential is lost by God's lack of knowledge of the specific tensed truth, so long as God knows the corresponding untensed version of that truth. (So God knows that, for example, the movie finished at such-and-such a time, but not that, at a previous time, it is nearly finished).

The more difficult case is clearly that of foreknowledge and free will. There is, of course, the option mooted above of insisting that the relevant facts are not determined yet, and hence that there is nothing for God to know in this regard, bar general future trends. ${ }^{5}$ That line is controversial, not least because it seems that it is compatible with God knowing a great deal about what one is about to do (even if that knowledge doesn't extend too far into the future), and that might itself suffice to undermine a great deal of human freedom (at least insofar as it is accepted that knowledge of the future undermines free will at any rate).

My interest, however, is in a different line of response, whereby one argues that there can be propositions which God can legitimately not know. For example, the starting point of perfect being theology is to consider God as the most perfect being possible and work back from there in terms of determining his properties. Insofar as one is persuaded that such a being must have the properties traditionally ascribed to God - such as omniscience, perfect goodness, omnipotence, and so on - and that these properties can potentially conflict, then one could reasonably conclude that a perfect being will instantiate these properties only to the extent that they can be instantiated, consistent with all of them being possessed. That would give one a principled basis for restricting God's knowledge of the future, insofar as one grants that such knowledge would be incompatible with human freedom (and thus with God's perfect goodness, which requires allowing such freedom). ${ }^{6}$

Of course, there would still be the vexed question of how this limitation is effected. Could God choose to ignore certain truths, or could he choose to forget what he knows? In the former case, since God doesn't need to acquire knowledge in the first place, it's hard to see how willful ignoring would work, as that only seems applicable to beings like us who do need to gain our knowledge (and thus can choose not to acquire certain forms of knowledge). In the latter case, it is difficult to understand how forgetting is even possible for a being like God. It is challenging enough for a human being to consciously forget what she knows, as trying to forget something is liable to make it more memorable.? But at least one can have some confidence that one's fallible cognitive powers might eventually lead one to be unable to recall the target fact. God, however, can have no such confidence.

Let's grant that some way is found to ensure that one of these strategies is effective, and hence that God lacks knowledge of the target propositions. One advantage that solutions to the problems posed by omniscience of this kind have is that they at least avoid the implication that God's lack of complete knowledge is due to a cognitive limitation on his part. The idea is rather that God could have had the knowledge in question - i.e., there is no cognitive barrier to him possessing it - it is just that through an act

\footnotetext{
4 This issue might perhaps be handled via appeal to Zagzebski's $(2008,2013 \mathrm{~b}, 2016)$ notion of omnisubjectivity, as described in endnote 2 . For versions of this line of response, see Geach (1977), Hasker (1989, 2004), Hoffman and Rosenkrantz (2002), Mawson (2019), and Swinburne (2016).

6 For a recent discussion of perfect being theology, see Nagasawa (2017). See also Langtry (2008) and Mawson (2019).

It is challenging even for an agent to simply set aside what she knows in her deliberations. This is one reason why legal scholars are concerned about the practice of judges asking jurors to disregard information in the context of a criminal trial. See, for example, Kassin and Sommers (1997)
} 
of will, one guided by his inherent goodness, he elects not to possess it. This suggests a kind of mitigated omniscience. Bruce Langtry (2008, 39), for examples, suggests that God is omniscient just in case, for every true proposition $p$, "either God knows that $p$, or else he does not but his knowing that $p$ is not precluded by any defect or limitation in his intrinsic cognitive capacities." Cases where God elects not to know a certain proposition would clearly satisfy the second disjunct.

3. Such mitigated omniscience looks like one plausible way out of the problem posed by omniscience. But there is a standing concern about any such proposal, which is how it plays out once one relates this view to the dominant account of ignorance in the literature. This is the proposal that ignorance is simply the lack of knowledge, such that lacking knowledge that $p$ entails that one is ignorant that $p .{ }^{8}$ It would thus follow on this view that God is not only not all-knowing, but more importantly that he is ignorant of what he does not know, even despite the excellent reasons he has for not knowing it (reasons that are rooted in his inherent goodness). The concern, however, is that ignorance looks like more than simply a descriptive claim about one's lack of knowledge, but also a normative claim about the agent. Ignorance is something to be ashamed of, for example; it is certainly not something to be proud of. Relatedly, once one becomes aware of one's ignorance, one should try to remedy it if one can; one should not consciously embrace it as a long-term strategy. God's mitigated omniscience, however, is precisely a form of non-knowledge - and thus (on the standard view) ignorance - that is the result of a conscious strategy, and which God will accordingly not remedy. Is it really plausible that God is not only ignorant, but actually consciously embraces ignorance, thereby making him subject to the negative normative assessment that this seems to entail?
I want to suggest that the right way to think about mitigated omniscience is not merely such that it is God's deliberate not-knowing, and hence involves no cognitive limitation on his part, but also that this not-knowing has the kind of properties that exclude it from being a case of ignorance. In short, while God might not know all truths, he is certainly not ignorant of any truths. In order to make this claim stick, I will need to argue against the standard view of ignorance as the lack of knowledge. In particular, I will be claiming that one's lack of knowledge of a set of truths does not entail that one is ignorant of those truths, as there can be cases of non-knowledge which aren't thereby cases of ignorance. This will open up the logical space required in order to maintain that mitigated omniscience needn't entail that God is ignorant of what he doesn't know. In addition, I will be arguing that the particular way in which God lacks knowledge according to mitigated omniscience involves a kind of not-knowing that excludes ignorance.

4. Before we get to these claims, however, we first need to comment on the main competitor account of ignorance to the standard lack of knowledge view. After all, one might think that in rejecting the standard account of ignorance, I am thereby endorsing this competing proposal. In fact, as we will see, the competing proposal is just as problematic as the standard view, and would not in any case offer any assistance when it comes to the question of whether mitigated omniscience entails ignorance.

The alternative account of ignorance in the literature - the so-called 'New View' - is that ignorance is not the lack of knowledge but rather the lack of true belief. ${ }^{9}$ Since we will be rejecting both the new view and the standard account of ignorance, we needn't dwell too long on the rationales that have been offered in favour of the former, but one can see how a case could be mounted in its defence. For example, if one

\footnotetext{
8 For some key defences of this position, which is usually referred to as the 'standard view' on account of its widespread adoption, see Zimmerman (2008), Le Morvan (2011, 2012, 2013), and DeNicola (2017).

9 For some of the main defences of the new view of ignorance, see Goldman and Olsson (2009), van Woudenberg (2009), and Peels (2010; cf. Peels 2011, 2012).
} 
has a true belief that falls short of knowledge because it is Gettiered, say - then would that really suffice to ensure that one is thereby ignorant? If one is tempted to respond in the negative, then this would thus be one reason for thinking that something less than knowledge, such as mere true belief, can suffice to exclude ignorance. ${ }^{10}$

In any case, thinking about ignorance as the absence of true belief rather than knowledge might initially seem to give us a way of resisting the putative entailment from mitigated omniscience to ignorance. After all, that God doesn't know the target truths needn't entail that he doesn't believe them, and thus it would follow on this view that his lack of knowledge doesn't entail that he is thereby ignorant.

Unfortunately, this line of argument doesn't stand up to closer scrutiny. In particular, we should notice that the cases in which subjects have true beliefs while lacking the corresponding knowledge - and so, on this view at least, are not ignorant of the target propositions even though they fail to know them - essentially trade on our human cognitive fallibility. It is because of such cognitive fallibility, for example, that one lacks knowledge in a Gettier-style case even while having a true belief (a true belief that, moreover, enjoys epistemic justification).

The problem, however, is that such cognitive fallibility seems completely inapplicable when it comes to God. In particular, how could God have a true belief in a proposition without thereby knowing it? In order to make this possibility coherent, we would need to imagine that there is either something amiss with God's cognitive capacities or that the knowledge is lacking instead because of unusual features of the circumstance that ensure that even a well-formed true belief doesn't amount to knowledge (e.g., that the belief is Gettiered). But neither possibility is plausible in the case of God.

The former option is implausible because there is nothing amiss with God's capacities, as he is, by hypothesis, epistemically perfect (or at least epistemically optimal). It would, in any case, clearly be pointless to try to account for God's mitigated omniscience without ascribing ignorance to him by in the process treating him as cognitive deficient. The latter option is dubious for similar reasons. We can account for how even well-formed true belief might not lead to knowledge for human agents by supposing that their true belief is embedded within a wider set of beliefs that either contains some significant falsehoods or the absence of salient true beliefs. Think, for example, of how a Gettierstyle case works, such as when the subject forms a (justified) true belief about the barn in front of them while being blissfully unaware that they are in barn-façade county where most bard-shaped objects are not genuine barns. But that's hardly a credible strategy in this case, as it would involve accounting for God's mitigated omniscience in the putative absence of ignorance by actively attributing a wider ignorance to God (even by the lights of this specific account of ignorance).

It follows that the new view of ignorance is no more able to account for how God's mitigated omniscience doesn't lead to ignorance than the standard view of ignorance. The only difference is that while, in the latter case, the route from mitigated omniscience to ignorance is direct (since any lack of knowledge straightforwardly entails ignorance), in the former case the route is more circuitous (as it goes via the point that God cannot coherently truly believe a proposition without knowing it), even though the destination in the same.

Crucially, however, both the standard and the new view of ignorance are implausible on closer inspection. Moreover, once we understand why they are untenable proposals, then we get to see how there could be propositions that subjects fail to know (and even, for that matter, fail to truly believe) which they are not thereby ignorant of. The crux of the matter is that ignorance captures a normative status in that to be ignorant of a truth is not merely to lack the relevant knowledge (or

10 The two main contemporary accounts of ignorance - the 'standard view' and the 'new view' - are usefully surveyed in Le Morvan and Peels (2016). Note that we are here focusing on propositional forms of ignorance, just as we are focusing on propositional omniscience. See Nottelman (2015) and El Kassar (2018) for two recent discussions of non-propositional forms of ignorance and how they relate to the propositional variety. 
true belief), but more specifically involves one's lack of knowledge (or true belief) manifesting a kind of failing or deficiency in one's intellectual character. The upshot is that so long as one's lack of knowledge is intellectually appropriate, and so involves no intellectual failing on one's part of this kind, then it is not a case of ignorance.

5. Consider, for example, truths that are in principle unknowable. For instance, the Wittgensteinian notion of a hinge commitment is meant to pick out a particular kind of background certainty that is simply not in the market for knowledge. ${ }^{11}$ Suppose that there are propositions of this kind, whereby one is certain of them, but one cannot know them. While one's epistemic situation is clearly one of lacking knowledge of these truths, it would be very odd to describe one as thereby ignorant of them, given that they are in principle unknowable. In particular, to describe someone as ignorant at the very least implies a kind of intellectual failing on their part, and in this case this is clearly lacking, as no subject could know these propositions.

What goes for in principle unknowable truths also applies to truths that are practically unknowable, such that there is no feasible inquiry available to discover them. Many truths about the past are like this, such as the truth about what Caesar had for breakfast on the day that he crossed the Rubicon. Discovering new historical sources of information in this regard is highly unlikely, both because we are already aware of all the relevant sources, and because even if there were new sources they are unlikely to cover this topic anyway. Short of some sort of time travelling device (which is, again, highly unlikely), there is thus no practical way of finding out this truth: it is practically unknowable, even if not in principle unknowable. As with unknowable truths, however, we would not call someone ignorant because they failed to know truths of this kind, as clearly this lack of knowledge would not indicate an intellectual failing on their part. Indeed, it would rather be an intellectual failing were one to actively inquire about truths that are clearly unknowable, either in the practical or in principle sense.

There are other truths where there is no intellectual failing involved in not inquiring about them, even when the truths are practically knowable. I don't know how many spoons there presently are in my immediate neighborhood. This isn't because it is practically unknowable; indeed, it would be very straightforward (if time consuming) to find out - one would simply need to go door-to-door making the relevant inquiries. There is absolutely no reason to find out this truth, however, still less to invest the necessary time in making the relevant inquiries that would be required. Accordingly, while this is a truth that I do not know, I am not thereby ignorant of it, as my lack of knowledge doesn't indicate an intellectual failing on my part. Indeed, as with the other two cases, it would indicate an intellectual failing were I to attempt to discover this truth. ${ }^{12}$

Compare these cases with the kinds of scenarios where it does seem fitting to depict someone as ignorant. For example, we might describe a colleague as ignorant of other cultures. The implication is clear. This person could easily find out about other cultures, but due to an intellectual failing on their part - at the very least a lack of curiosity, but perhaps something more sinister, such as an incuriosity that is rooted in tacit racism or xenophobia - they do not make inquiries of this kind. Their lack of knowledge thus has a normative dimension that qualifies it as ignorant: it is not just that they lack knowledge, but more

\footnotetext{
11 See Wittgenstein (1969). Hinge commitments are a controversial notion, as is this particularly way of thinking about them, but that doesn't matter for our purposes, as all we require is that they are conceivable, so construed, and that is surely true. For further discussion of this way of characterizing hinge commitments, see Pritchard (2015). For a recent alternative account of hinge commitments, see Schönbaumsfeld (2016).

12 Although I have focused on the competing standard view of ignorance as lack of knowledge in this regard - on account of its obvious relevance to mitigated omniscience - it should be clear that the problem cases just described equally present difficulties for the new view of ignorance as lack of true belief. In the case of the practically unknowable truths and the trivial truths that one ought not to inquire into, the non-ignorant subject is both lacking true belief and knowledge. Although more controversial, it has also been suggested that our hinge commitments are not only unknowable, but also not the kind of commitment that amounts to a belief, at least in the sense that epistemologists have in mind anyway (see Pritchard, 2015, part 2). If so, then the case of unknowable truths would also illustrate how lack of true belief needn't lead to ignorance.
} 
specifically that their lack of knowledge reveals an intellectual failing, in this case incuriosity.

In contrast, we would not describe a young child as ignorant of other cultures, even if it was clear that they knew very little in this regard, as the normative dimension is lacking. The child is not yet at a stage where it would make sense to credit them with the relevant intellectual failing for not making the relevant inquiries, and so to depict them as ignorant would be unfair, even though they clearly lack the target knowledge. In particular, just as in the cases described above where lack of knowledge coexists with a lack of ignorance, the child hasn't exhibited any deficiency in their intellectual character by failing to possess this knowledge.

6. The point of the foregoing is that lack of knowledge doesn't entail ignorance, as the latter further requires that the lack of knowledge in question indicates an intellectual failing. Moreover, we have seen that there can be truths that one doesn't know where there is no failing of this kind. The lack of knowledge is accordingly intellectually appropriate, and hence not a case of ignorance. ${ }^{13}$ If that's right, then this opens up the logical space to contend that the lack of knowledge attributable to God as part of the mitigated omniscience strategy need not lead to ignorance.

Merely demonstrating that the logical space is available, however, is clearly not enough, as one needs to further show that the proponent of mitigated omniscience can exploit this possibility. Furthermore, this is easier said than done. In particular, even if one accepts this distinction, one might contend that it has no application to the issues posed by God's omniscience on the grounds that the relevant cases where knowledge and ignorance come apart don't apply to God's unique epistemic position. Indeed, the kinds of cases that we just looked at seem to confirm this.

The idea that our hinge commitments are unknowable is clearly meant to be a claim about human knowledge. The hinges are unknowable because the kind of primitive certainty that they concern needs to be in place in order for our social practice of reason-giving to function. God's knowledge, however, clearly isn't embedded into the fabric of the space of reasons in the way that human knowledge is, and thus there seems no inherent reason why any of the propositions picked out by a subject's hinge commitments should be unknowable for him.

The situation is even more stark when it comes to practically unknowable propositions, as of course such propositions are not practically unknowable for a being like God with such optimal epistemic powers, so the question of whether a failure to know them entails ignorance simply never arises (as the antecedent is never met). God's supreme epistemic powers also blocks the third kind of case that we cited, whereby some truths are unknown without this implying ignorance because no sensible inquirer would seek out these truths (as they are trivial and also time-consuming to discover). God, after all, will presumably already know such truths and hence issues of their triviality or the costs involved in acquiring these truths simply won't arise.

7. What the foregoing demonstrates is not, however, that the logical gap between ignorance and lack of knowledge fails to gain us a purchase on the issues that concern us regarding omniscience, but rather that if we are to understand how it gains such a purchase, then we need to expand our diet of cases where the two epistemic standings come apart. We've already noted that what the kinds of scenario describe above show is that we don't attribute ignorance to subjects who lack knowledge so long as this lack of knowledge doesn't manifest an intellectual failing on the part of the subject. In particular, there can be cases where it is intellectually appropriate for the subject to lack knowledge, and in those scenarios an ascription of ignorance would not be apt.

Notice, however, that the scenarios we looked at earlier also concern cases of intellectual propriety where the subject is sensitive to

13 I develop this account of ignorance in more detail in Pritchard (2021) 
reasons of a purely practical kind, such as when a subject elects not to undertake an arduous inquiry to discover a truth that is of no practical significance. That is, intellectual propriety here doesn't just involve epistemic factors, such as (epistemic) reasons and evidence, but a wider rational sensitivity to all relevant considerations. The relevant sense of an intellectual failing in play (i.e., of a kind that leads to ignorance) is thus one that isn't confined to an insensitivity to purely epistemic factors, but can include a rational insensitivity to any relevant considerations. This is important for our purposes, since if purely practical considerations can be significant in this regard, then so too can moral considerations.

Indeed, I think this is just what we find when we start to examine cases with the relevant structure. For example, a parent discovers a child's diary, wherein they know they will find all sorts of information about what that child has been up to. But now imagine that the parent decides that it would be wrong to invade their child's privacy in this way, and so opts not to look at the contents of the diary. Is the parent now ignorant of the truths in the diary that she doesn't know? Or consider another case. A police investigator is accidentally given documents by the accused's lawyer which would bear on his guilt. The police investigator realizes, however, that it would be immoral (not to mention unlawful) for him to read the documents and hence returns them to the lawyer unopened. Is the police investigator now ignorant of the truths in the document that she doesn't know?

I think it is clear that we wouldn't naturally treat the subjects involved as being ignorant. Moreover, our previous diagnosis of what is going on in ascriptions of ignorance explains this. For in both cases our subject is being appropriately responsive to rational considerations that are guiding their inquiry, such that while they do not gain knowledge, their lack of knowledge is not due to an intellectual failing on their part. It does not matter that the rational considerations in play are specifically moral.

Notice too that a lack of knowledge that was the result of subjects being inappropriately responsive to the rational considerations in question would be compatible with the subject being deemed ignorant. For example, if the parent doesn't look in the diary because they fear that it would make them sympathetic to the child's point of view, and they prefer to remain unsympathetic, then this would not absent them from being ignorant. Or if our detective opted not to read the documents because they realized that to do so would generate additional onerous paperwork that they wish to avoid, then this wouldn't absent them from being ignorant either. It is thus important that the subject's inquiry does not lead to knowledge as a result of the subject being appropriately responsive to rational considerations, including moral considerations, that are relevant to that inquiry.

The cases just offered differ from the scenarios presented above in at least one interesting way. In the previous set of cases we noted that were the subject to undertake the inquiry in question regardless - into the unknowable truth, say, or regarding the pointless truth - then that would itself represent an intellectual failing. This doesn't seem to be the case in the scenarios just described where the subject is being appropriately responsive to a moral consideration. This suggests an asymmetry between the way in which a good inquirer - from a purely intellectual point of view - ought to be responsive to moral as opposed to practical considerations. Whereas the good inquirer should be responsive to practical considerations, it seems that being appropriately responsive to moral considerations is merely optional from the exclusive perspective of good inquiry. That is, while lacking knowledge as a result of being appropriately responsive to moral considerations can suffice to ensure that this lack of knowledge doesn't amount to ignorance - just as it does, mutatis mutandis, in the case of being appropriately responsive to practical considerations - if one opts to gain this knowledge even despite the moral considerations involved, one is not thereby manifesting a failing qua inquirer (as one does in the practical case), even if one is manifesting a moral character failing. Nonetheless, the point remains that being appropriately responsive to moral considerations can suffice to ensure that the lack of knowledge that directly results is not thereby an instance of ignorance. 
8. With this further kind of case in support of the logical gap between lack of knowledge and ignorance, we can return to see how it applies to the case of God's mitigated omniscience. Let's go back to the issue about free will and omniscience that we noted above. Let's suppose that God could coherently limit his knowledge of the future such as to allow us to have free will, so that while he would presumably know enough about his subjects to have a fair idea of what we are likely to do next, he doesn't know what we will do next (at least once one focusses on any substantive distance in the future). As we noted earlier, this would be a self-imposed limitation in God's knowledge of the future that is rooted in his own goodness. As a self-imposed limitation, it would not reveal any inherent cognitive weakness on God's part, as the knowledge would be available to him were he to choose to possess it. What is most relevant for our purposes, however, is that this self-imposed limitation of knowledge is rooted in God's goodness, and hence cannot but involve an appropriate responsiveness to a moral consideration. That should accordingly suffice to ensure that this lack of knowledge is not ignorance, particularly once we further bear in mind that it is a self-imposed lack (and so does not reveal a cognitive limitation).

There is one key difference between how we are thinking of human ignorance and the application of ignorance to the case of God. This is that we are naturally casting the former in terms of an intellectual failing qua inquirer, and yet it is difficult to even make sense of God as inquiring, at least in anything like the way that we inquire. God's supreme cognitive powers mean that there is no need to inquire in order to gain knowledge, as the knowledge is immediately available to him. If God doesn't inquire, then how can he exhibit an intellectual failing of inquiry? Doesn't it thereby trivially follow that God is never ignorant of what he does not know?

While I think it is right that God simply cannot be ignorant, I do not think that this point trivially follows from God's nature, much less does it relate to the fact that God does not undertake inquiries in order to gain knowledge as we do. It is natural to express the normative dimension of ignorance in terms of inquiry because it is in the context of inquiry that human beings manifest the relevant kind of intellectual failing. But what is important to this account of ignorance is not the particular vehicle by which the relevant intellectual failing is made manifest in human beings, but rather the more general idea that ignorance is a negative normative standing that indicates an intellectual failing on the part of the subject - specifically, an inappropriate responsiveness to rational considerations that bear on the matter in hand.

So construed, it is easy to see why God simply cannot be ignorant, in that a supreme being will hardly be inappropriately responsive to the rational considerations in play. But I don't think that this thereby makes the point that God is lacking in ignorance trivial, as it would if it merely fell out of the fact that God is not an inquirer. This is because this claim about God's lack of ignorance follows from a substantive thesis about the nature of ignorance and an account of the specific manner in which God's lack of knowledge would be manifest. Indeed, far from being trivial, the claim in play is actually surprising, at least to the extent that to my knowledge it has not previously been noted (even as a dialectical option).

9. My contention, then, is that God's mitigated omniscience, properly understood, does not entail that he is ever ignorant of what he does not know. In particular, God's lack of knowledge, being selfimposed, doesn't reveal a cognitive limitation on his part (which would implausibly indicate lessthan-optimal epistemic powers). More importantly, since this lack of knowledge is grounded in his inherent goodness, and hence rooted in good moral reasons, this suffices to ensure that the lack of knowledge doesn't entail ignorance. In particular, with the lack of knowledge so rooted in good moral reasons, it cannot have the normative dimension that would entail ignorance.

God's lack of knowledge thus does not indicate a cognitive lack, nor is it grounds for attributing ignorance to God. God might not know everything. but there is nothing of which he is ignorant, nor is there (so far as we have specified anyway) any truth that he lacks a cognitive means of knowing. 


\section{References}

ALSTON, W. P. Does God Have Beliefs? Religious Studies, [S. I.], n. 22, p. 287-306,1986

CRAIG, W. L. Divine Foreknowledge and Human Freedom: The Coherence of Theism: Divine Omniscience. Leiden: Brill, 1991.

DENICOLA, D. R. Understanding Ignorance: The Surprising Impact of What We Don't Know. Cambridge, MA: MIT Press, 2018.

EL KASSAR, N. 'What Ignorance Really Is: Examining the Foundations of Epistemology of Ignorance'. Social Epistemology, [S. I.], n. 32, p. 300-310, 2018.

KASSIN, S. M.; SOMMERS, S. R. Inadmissible Testimony, Instructions to Disregard, and the Jury: Substantive Versus Procedural Considerations. Personality and Social Psychology Bulletin, [S. I.], n. 23, p. 1046-1054, 1997.

GEACH, P. T. Providence and Evil. Cambridge: Cambridge University Press, 1977.

GOLDMAN, A.; OLSSON, E. Reliabilism and the Value of Knowledge. In: HADDOCK, A.; MILLAR, A.; PRITCHARD, D. H. (ed.). Epistemic Value. Oxford: Oxford University Press, 2009. p. 19-41.

GRECO, J. Achieving Knowledge. Cambridge: Cambridge University Press, 2009.

HASKER, W. Yes, God Has Beliefs. Religious Studies, IS. l.], n. 24, p. 385-394, 1988.

HASKER, W. God, Time, and Knowledge. Ithaca, NY: Cornell University Press, 1989.

HASKER, W. Providence, Evil and the Openness of God. London: Routledge. 2004.

HOFFMAN, J.; ROSENKRANTZ, G. S. The Divine Attributes. Oxford: Blackwell, 2002

KVANVIG, J. L. The Possibility of an All-Knowing God. London: Palgrave Macmillan, 1986.

LANGTRY, B. God, the Best, and Evil. Oxford: Oxford University Press, 2008.

LE MORVAN, P. Knowledge, Ignorance and True Belief. Theoria, [S. I.], n. 77, p. 32-41, $2011 a$.

LE MORVAN, P. On Ignorance: A Reply to Peels. Philosophia, [S. I.], n.39, p. 335-344, 2011 b.

LE MORVAN, P. On Ignorance: A Vindication of the Standard View. Philosophia, [S. I.], n. 40, p. 379-393. 2012.

LE MORVAN, P. Why the Standard Conception of Ignorance Prevails. Philosophia, [S. I.], n. 41, p. 239-256, 2013).

LE MORVAN, P.; PEELS, R. (2016). The Nature of Ignorance: Two Views. In: PEELS, R.; BLAAUW, M. (ed.). The Epistemic Dimensions of Ignorance Cambridge: Cambridge University Press. p. 12-32.

MAVERODES, G. I. Omniscience. In: C. Taliaferro, DRAPER, P.; QUINN, Philip L. (ed.). A Companion to Philosophy of Religion. 2. ed. Oxford: Blackwell, 2010. p. 251-258.
MAWSON, T. J. The Divine Attributes. Cambridge: Cambridge University Press, 2019.

NAGASAWA, Y. Maximal God: A New Defense of Perfect Being Theology. Oxford: Oxford University Press, 2017.

NOTTELMANN, N. Ignorance. In: AUDI, R. (ed.). Cambridge Dictionary of Philosophy. 3. ed. Cambridge: Cambridge University Press, 2015. p. 497-498.

PEELS, R. What is Ignorance? Philosophia, [S. I.], n. 38, p. $57-67,2010$

PEELS, R. Ignorance Is Lack of True Belief: A Rejoinder to Le Morvan. Philosophia, [S. I.], n. 39, 344-355, 2011.

PEELS, R. The New View on Ignorance Undefeated. Philosophia, [S. I.], n. 40, p. 741-750, 2012.

PRITCHARD, D. H. Anti-Luck Virtue Epistemology. Journal of Philosophy, [S. I.], n. 109, p. 247-279, 2012.

PEELS, R. Epistemic Angst: Radical Skepticism and the Groundlessness of Our Believing. Princeton, $\mathrm{NJ}$ : Princeton University Press, 2015

PEELS, R. (2021). 'Ignorance and Inquiry', American Philosophical Quarterly 58, 111-23.

SCHÖNBAUMSFELD, G. The Illusion of Doubt. Oxford: Oxford University Press, 2016.

SOSA, E. A Virtue Epistemology: Apt Belief and Reflective Knowledge. Oxford: Oxford University Press, 2007.

SWINBURNE, R. The Coherence of Theism. 2. ed. Oxford: Oxford University Press, 2016.

VAN INWAGEN, P. What Does an Omniscient Being Know about the Future? Oxford Studies in Philosophy of Religion, [S. I.], n. 1, p. 216-230, 2008.

VAN WOUDENBERG, R. Ignorance and Force: Two Excusing Conditions for False Beliefs. American Philosophical Quarterly, [S. I.], n. 46, p. 373-386, 2009.

WAINWRIGHT, W. J. Omnipotence, Omniscience, and Omnipresence. In: TALIAFERRO, C.; MEISTER, C. (ed.). Cambridge Companion to Christian Philosophical Theology. Cambridge: Cambridge University Press, 2010. p. 46-65.

WIERENGA, E. Omniscience. In: FLINT, T. P.; REA, M. C (ed.). Oxford Handbook of Philosophical Theology. Oxford: Oxford University Press, 2009. p. 129-144.

WIERENGA, E. Omniscience. In: ZALTA, E. Stanford Enclyclopedia of Philosophy. [2021]. Available in: https://plato. stanford.edu/entries/omniscience. Acessed on: 4jul. 2021.

WITTGENSTEIN, L. On Certainty. Edited by G. E. M. Anscombe; G. H. von Wright;

Translated by D. Paul; G. E. M. Anscombe. Oxford: Blackwell, 1969.

ZAGZEBSKI, L. T. The Dilemma of Freedom and Foreknowledge. New York: Oxford University Press, 1991

ZAGZEBSKI, L. T. Omnisubjectivity. Oxford Studies in Philosophy of Religion, [S. I.], n. 1, p. 231-247, 2008. 
ZAGZEBSKI, L. T. Foreknowledge and Human Freedom. In: TALIAFERRO, C.; DRAPER, P.; QUINN, Philip L. (ed.). A Companion to Philosophy of Religion. 2. ed. Oxford: Blackwell, 2010. p. 474-482.

ZAGZEBSKI, L. T. Omniscience. In: MEISTER, C:; COPANS, P. (ed.). Routledge Companion to Philosophy of Religion. 2. ed. London: Routledge. 2013a. p. 309-319.

ZAGZEBSKI, L. T. Omnisubjectivity: A Defense of a Divine Attribute (Aquinas Lecture 2013). Milwaukee, WI: Marquette University Press, 2013b.

ZAGZEBSKI, L. T. Omnisubjectivity: Why It Is a Divine Attribute. Nova et Vetera, [S. I.], n. 14, p. 435-450, 2016.

ZIMMERMAN, M. J. Living with Uncertainty: The Moral Significance of Ignorance. Cambridge: Cambridge University Press, 2008.

\section{Duncan Pritchard}

PhD in Philosophy from the University of St. Andrews, Scotland, UK; Professor of Philosophy at the University of Irvine (UCI), CA, USA.

\section{Mailing address}

\section{Duncan Pritchard}

Department of Philosophy

University of California, Irvine

85 Humanities Instructional Building

Irvine, CA 92697-4555

USA

Os textos deste artigo foram conferidos pela Poá Comunicação e submetidos para validação do autor antes da publicação. 